\title{
Pengaruh variansi konsentrasi ekstrak kulit batang jambu mete terhadap sitotoksikitas sel fibroblas
}

\author{
H. Harsini* dan Ahmed Febri Noor Hertama** \\ *Departemen IImu Biomaterial, Fakultas Kedokteran Gigi, Universitas Gadjah Mada, Yogyakarta, Indonesia \\ **Program Studi Ilmu Kedokteran Gigi, Fakultas Kedokteran Gigi, Universitas Gadjah Mada, Yogyakarta, Indonesia \\ JI Denta No 1, Sekip Utara, Yogyakarta, Indonesia; e-mail: harsiniugm@yahoo.com
}

\begin{abstract}
ABSTRAK
Tujuan penelitian ini adalah untuk mengetahui kandungan ekstrak kulit batang jambu mete dan pengaruh variasi konsentrasi terhadap sitotosisitas sel fibroblas. Penelitian ini menggunakan bahan kulit batang jambu mete (Mojolegi) yang diindentifikasi dan diekstrak menggunakan metode maserasi dengan pelarut etanol $70 \%$. Ekstrak diuji kandungannya menggunakan metode KLT (Kromatografi Lapis Tipis). Uji sitotoksikistas menggunakan sampel sejumlah 15 dikelompokkan menjadi 5, masing-masing kelompok 3 (ISO-10993-5). Variasi konsentrasi adalah 1,6\%, 0,8\%, 0,4\%, 0,2\% dan 0,05\%. Uji sitotoksikitas menggunakan metode MTT dengan cara membandingkan optical density (ELISA plate reader) antar kelompok perlakuan dengan kelompok kontrol. Viabilitas sel didapatkan dengan membandingkan nilai optical density pada kelompok perlakuan dan kelompok kontrol. Data viabilitas sel dianalisis menggunakan ANAVA satu jalur dan LSD. Hasil penelitian menunjukkan rerata ekstrak mengandung senyawa asam anakardat dan asam galat. Uji sitotoksikistas sel fibroblas akibat variasi ekstrak kulit batang jambu mete secara berturut-turut dari konsentrasi $1,6 \%, 0,8 \%, 0,4 \%, 0,2 \%$ dan $0,05 \%$ dengan rerata sebesar $15,35 \% \pm 0,443,30,84 \% \pm 1,59,47,78 \% \pm 8,09,65,74 \% \pm 3,20,74,95 \% \pm 7,26$. Uji ANAVA menunjukkan adanya pengaruh variasi konsentrasi ekstrak kulit batang jambu mete bermakna terhadap viabilitas sel $(p<0,05)$. Hasil uji LSD menunjukkan bahwa terdapat perbedaan yang bermakna $(p<0,05)$ antar kelompok perlakuan, kecuali antara konsentrasi $0,05 \%$ dengan konsentrasi $0,2 \%$. Kesimpulan Ekstrak kulit batang jambu mete mengandung asam anakardat dan asam galat dan terdapat pengaruh variasi konsentrasi ekstrak kulit batang jambu mete terhadap sitotoksikitas sel fibroblas. Konsentrasi $0,2 \%$ merupakan konsentrasi yang tidak toksis terhadap sel fibroblas secara in vitro
\end{abstract}

Kata kunci: bahan kumur, ekstrak kulit batang jambu mete, MTT assay, sel fibroblas

\begin{abstract}
The influence of cashew stembark extract on citotoxicity fibroblast. The aim of this study was to determine the effect of variation in the concentration of cashew stem bark extract as the base material of mouthwash of the cytotoxic effect on fibroblast cells. The material used in this study was cashew stem bark extracted by maceration method using $70 \%$ of ethanol. A total of 15 samples were grouped into 5, each of which consisted of 3 samples (ISO 10993-5). Concentrations used were $1.6 \%, 0.8 \%, 0.4 \%, 0.2 \%$ and $0.05 \%$. Cytotoxicity test used the MTT method by comparing the optical density (ELISA plate reader) between treated groups with control groups. Cell viability was obtained by comparing the treated groups with control groups. Cell viability data was analyzed using one-way ANOVA and LSD. The results showed that cashew stem bark has an anticardia acid. Cytotoxicity test used the mean of fibroblast cell viability due to various cashew stem bark extracts successively from concentrations $1.6 \%, 0.8 \%, 0.4 \%, 0.2 \%$ and $0.05 \%$ with the mean of $15.35 \pm 0.443 \%, 30.84 \%$ $\pm 1.59,47.78 \pm 8.09 \%, 65.74 \% \pm 3.20,74.95 \pm 7.26 \%$. ANOVA showed a significant influence of various cashew stem bark on cell viability $(p<0,05)$. The results of $L S D$ showed a significant difference between treated groups except between concentrations $0.95 \%$ and $0.2 \%$. In conclusion, Cashew extract have anacardic acid and there was influence on various cashew stem bark extract concentrations on the cytotoxicity of fibroblast cell. The concentration of $2 \%$ was not cytotoxic.
\end{abstract}

Keywords: mouthwash, cashew stem bark extract, MTT assay, cell fibroblast

\section{PENDAHULUAN}

Stomatitis aftosa rekuren dikenal juga sebagai sariawan, recurrent aphthae, atau recurrent oral ulceration. Stomatitis aftosa rekuren merupakan radang yang terjadi di daerah mukosa mulut, biasanya berupa bercak putih kekuningan dapat tunggal maupun kelompok dengan permukaan yang agak cekung. Salah satu penanganan stomatitis aftosa dapat menggunakan bahan kumur. ${ }^{1}$ Tujuan pemakaian bahan kumur adalah mengantarkan bahan aktif untuk membersihkan permukaan gigi atau jaringan yang akan menghasilkan efek perawatan yang terbaik. ${ }^{2}$ Bahan penyusun yang terdapat di dalam larutan kumur diantaranya adalah air, alkohol, zat pemberi rasa dan bahan pewarna. Kandungan lainnya berupa humektan, astringen, zat pengemulsi dan bahan-bahan terapeutik. ${ }^{3}$ Bahan kumur yang mengandung alkohol dapat menyebabkan 
efek multipel yang tidak menguntungkan bagi penggunaannya, termasuk diantaranya adalah sensasi terbakar akibat kontak dengan mukosa mulut. ${ }^{4}$ Akhir-akhir ini dikembangkan bahan herbal yang mempunyai efek samping yang minimal. ${ }^{5}$

Jambu mete mempunyai nama latin Anacardium occidentale Linn merupakan salah satu tanaman yang banyak manfaatnya mulai dari akar, batang, daun dan serta buahnya. ${ }^{6,7}$ Kulit batang pohon jambu mete dapat digunakan sebagai bahan kumur untuk mengobati sariawan. ${ }^{8}$ Kulit batang jambu mete mengandung senyawa fenolik. ${ }^{9}$ Penyusun getah kulit batang jambu mete terdiri dari asam anakardat dan kardol. ${ }^{10}$ Senyawa fenolik dengan rantai samping yang relatif panjang mempunyai sifat iritan pada kulit. ${ }^{11}$ Senyawa fenolik dapat mendenaturasi protein dari membran sel sehingga menyebabkan perubahan permeabilitas. Perubahan permeabilitas menyebabkan air masuk ke dalam sel yang akan mengakibatkan hidrolisis sel dan sel mati. ${ }^{12}$ Profil sitotoksikitas dari tanaman selalu menjadi pertimbangan dalam pemakaian tanaman sebagi obat, terutama dalam penentuan dosis. ${ }^{13}$

Pada penelitian Tedong ${ }^{14}$ tentang akut dan subkronis toksikitas ekstrak daun jambu mete pada mencit, menunjukkan bahwa ekstrak daun jambu mete memiliki potensi toksikitas Salah satu syarat bahan kumur adalah tidak toksik terhadap sel manusia. Untuk mengukur sitotoksikitas suatu bahan salah satu menggunakan uji in vitro. ${ }^{15}$ Sel fibroblas adalah sel yang paling banyak digunakan untuk uji sitoksikitas material di bidang kedokteran gigi. ${ }^{16}$ Uji MTT digunakan untuk menguji aktivitas enzimatik pada sebuah sel. Prinsip dari Uji MTT yaitu terjadinya mekanisme perubahan warna kuning dari garam tetrazolium yang tereduksi menjadi kristal formazan dalam mitokondria sel hidup. ${ }^{17}$ Tujuan penelitian ini adalah mengetahui kandungan ekstrak kulit batang jambu mete sebagai dasar bahan kumur dan pengaruh variansi konsentrasi terhadap sitotoksikitas sel fibroblas.

\section{METODE PENELITIAN}

\section{Pembuatan ekstrak kulit batang jambu mete}

Pada penelitian ini digunakan kulit batang jambu mete yang diambil dari pohon jambu mete yang berada di daerah Mojolegi, Karang Tengah, Imogiri, Yogyakarta. Pembuatan ekstrak menggunakan cara maserasi dengan pelarut alkohol $70 \%$. Satu kilogram kulit batang jambu mete dibersihkan kulit luarnya dan dicuci bersih di bawah air mengalir, setelah itu diiris kecil-kecil dan dikeringkan menggunakan oven dengan suhu $40-50{ }^{\circ} \mathrm{C}$ selama kurang lebih $1 \times 24$ jam. Setelah kering, kulit batang jambu mete dibuat menjadi serbuk dengan menggunakan blender kecil dan ditimbang. Serbuk seberat $300 \mathrm{~g}$ dilarutkan dalam etanol $70 \%$ sebanyak 1 liter dan didiamkan selama 24 jam. Selanjutnya dipisahkan dengan cara disaring menggunakan corong buchner yang dilapisi kertas saring sehingga diperoleh filtrat dan ampas. Filtrat yang diperoleh diuapkan dengan menggunakan waterbath sehingga diperoleh ekstrak kental (Depkes, 2000). Selanjutnya ekstrak kental tersebut dideteksi menggunakan kromatografi lapis tipis untuk melihat kandungannya.

\section{Analisis asam anakardat dan asam galat pada ekstrak}

Analisis senyawa yang terkandung dalam kulit batang jambu mete dilakukan dengan menggunakan senyawa fenolik yaitu asam galat dan asam anakardat sebagai parameter spesifik senyawa yang terkandung di dalam ekstrak kulit batang jambu mete menggunakan Kromatografi Lapis Tipis (KLT). Pada metode KLT, fase diam yang digunakan yaitu silika gel $60 \mathrm{~F}_{254}$, sedangkan fase gerak yang digunakan yaitu n-propanol : asam asetat : air $(3: 1: 1 \mathrm{v} / \mathrm{v} / \mathrm{v})$.

Pada KLT, seberat $100 \mathrm{mg}$ ekstrak dilarutkan dalam $1 \mathrm{~mL}$ metanol. Pembanding yang digunakan adalah asam galat dan asam anakardat $10 \mathrm{mg} / \mathrm{mL}$ dalam pelarut etanol. Penotolan sampel ekstrak kulit batang jambu mete sebesar $1 \mu \mathrm{L}$ kemudian dimasukkan dalam fase gerak sampai terdeteksi zat yang ada dalam silika. Kemudian dideteksi pada semprotan lodium dan vanilin Sulfat pada sinar tampak, $\mathrm{UV}_{254}$ dan $\mathrm{UV}_{366}$.

\section{Uji Sitotoksikitas menggunakan metode MTT}

\section{a. Pembuatan kultur sel}

Sel yang digunakan adalah sel vero fibroblas yang berasal dariginjal kera hijauAfrika (Cercopitheus aethiops). Pada tahap pemeliharaan kultur sel vero, media kultur dari sel vero monolayer di M199 K yang konfluen dibuang kemudian sel dibilas dengan $10 \mathrm{~mL}$ M199. Ditambahkan tripsin-EDTA sebanyak 
$5 \mathrm{~mL}$ dan inkubasi sel dilakukan pada suhu $37^{\circ} \mathrm{C}$ selama $2-3$ menit sampai terlihat tanda sel mulai terlepas dari flask sel akan berbentuk bulat-bulat. Selanjutnya, $5 \mathrm{~mL}$ media kultur M199 disuplementasi dengan $10 \%$ fetal bovine serum (FBS) ditambahkan agar tripsin-EDTA menjadi tidak aktif. Sel dibilas di dalam media dan pipet digunakan secara perlahan untuk menguraikan gumpalan sel. Suspensi sel dipindahkan dari flask ke dalam tabung kerucut (conical tube) $15 \mathrm{~mL}$ steril kemudian disentrifugasi selama 5 menit pada suhu ruangan. Supernatan dibuang dan sel disuspensi kembali menggunakan $10 \mathrm{~mL}$ M199 dengan 10\% FBS. Pengenceran sel yang diinginkan dipersiapkan dari total $12-20 \mathrm{~mL}$ M199 dengan 10\% FBS dan ditambahkan ke dalam flask kultur sel.

\section{b. Pemberian ekstrak kulit batang jambu mete pada Vero cell line dengan metode MTT menurut ISO 10993-5 (2009)}

Setiap sumuran pada 96 sumuran microtitter tissue plate diisi sel fibroblas dengan kepadatan $2 \times 10^{4}$ sel / $100 \mu \mathrm{L}$. Kultur sel diinkubasi selama 24 jam. Sumuran diberi ekstrak kulit batang jambu mete dan diinkubasi selama 24 jam. Setelah kultur sel diinkubasi selama 24 jam, setiap sumuran diberi $100 \mu \mathrm{L}$ MTT, diinkubasi selama 4 jam pada suhu $37{ }^{\circ} \mathrm{C}$, lalu diberi $100 \mu \mathrm{L}$ Sodium Dodecyl Sulfate-Hydrochloric Acid (SDS-HCL), selanjutnya microplate dimasukkan pada ELISA plate reader dengan panjang gelombang $550 \mathrm{~nm}$. Pada uji MTT, nilai optical density (OD) diperoleh dari penghitungan terhadap jumlah kristal formazan yang terbentuk. Sitotoksikitas diukur berdasarkan viabilitas sel relatif terhadap kontrol dengan rumus sebagai berikut:

$$
\% \text { sel viabel }=\frac{\text { Optical Density Perlakuan }}{\text { Optical Density Kontrol }} \times 100
$$

\section{HASIL PENELITIAN}

Kandungan ekstrak kulit batang jambu mete yang dideteksi menggunakan kromatografi lapis tipis, memperlihatkan bahwa sampel kemungkinan mengandung senyawa asam galat dan asam anakardat karena sampel memiliki $h R_{\mathrm{f}}$ yang menyerupai $h R_{\mathrm{f}}$ asam galat dan asam anakardat sehingga dapat disimpulkan bahwa ekstrak kulit batang jambu mete secara maserasi mengandung senyawa asam galat (Gambar 1).
Penilaian sitotoksikitas Hasil nilai rerata persentase dan simpangan baku viabilitas sel fibroblas setelah penambahan ekstrak kulit batang jambu mete selama 24 jam tertera pada Gambar 2.

Hasil ANAVA pada Tabel 1 menunjukkan nilai $F_{\text {hitung }}>F_{\text {tabel }}$ bahwa variasi konsentrasi penambahan ekstrak kulit batang jambu mete terhadap viabilitas sel fibroblas menunjukkan pengaruh bermakna. Untuk mengetahui perbedaan rerata viabilitas antar kelompok sel fibroblas, dilakukan uji LSD yang rangkuman hasilnya disajikan pada Tabel 2 .

Berdasarkan hasil uji LSD pada Tabel 2 menunjukkan perbedaan rerata antar kelompok bermakna kecuali antara konsentrasi $0,2 \%$ dengan $0,05 \%$ yang menunjukkan adanya perbedaan tetapi tidak signifikan. Berdasarkan hasil ANAVA Tabel 1 dapat disimpulkan bahwa hipotesis yang menyatakan terdapat pengaruh variasi konsentrasi ekstrak kulit batang jambu mete terhadap sitotoksikitas sel fibroblas diterima.

\section{PEMBAHASAN}

Hasil penelitian tentang pengaruh konsentrasi ekstrak kulit batang jambu mete terhadap sel fibroblas pada Grafik 1 menunjukkan kecenderungan peningkatan rerata persentase kematian sel fibroblas terhadap penambahan konsentrasi ekstrak kulit batang jambu mete. Kematian sel disebabkan oleh toksisitas suatu material yang dipengaruhi oleh kandungan zat aktif dalam material tersebut. ${ }^{18} \mathrm{Hal}$ ini menunjukkan bahwa ekstrak kulit batang jambu mete mempunyai kandungan yang dapat meningkatkan persentase kematian sel fibroblas. Hasil ini sesuai dengan penelitian Toxnet ${ }^{19}$ menyatakan bahwa toksisitas suatu material yang mengandung fenol salah satunya dipengaruhi oleh konsentrasi fenol dalam material tersebut. Pada penelitian ini, pengaruh yang ditimbulkan ekstrak kulit batang jambu mete adalah kematian sel fibroblas karena adanya gangguan aktivitas enzimatik sel terutama enzim mitokondria dehydrogenase. Hal ini diperkuat oleh teori Cotran dkk.,20 yang menjelaskan bahwa rangsangan bahan toksik dapat menyebabkan jejas pada sel dengan cara merusak membran sel, mitokondria dan mengganggu substrat endogen sel. 


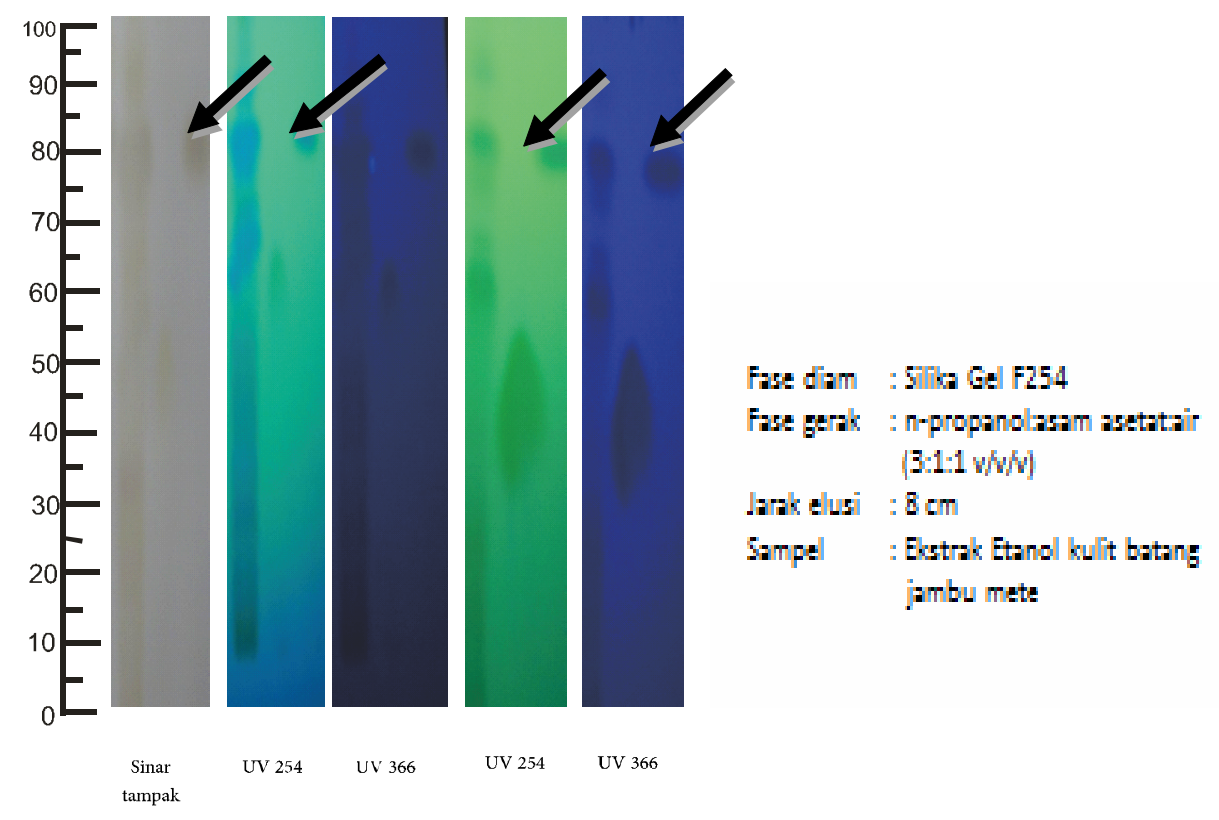

Gambar 1. Kromatogram ekstrak kulit batang jambu mete setelah disemprot menggunakan Vanilin Sulfat dan Uap lodium pada sinar tampak, $\mathrm{UV}_{254}$ dan $\mathrm{UV}_{366 .}$

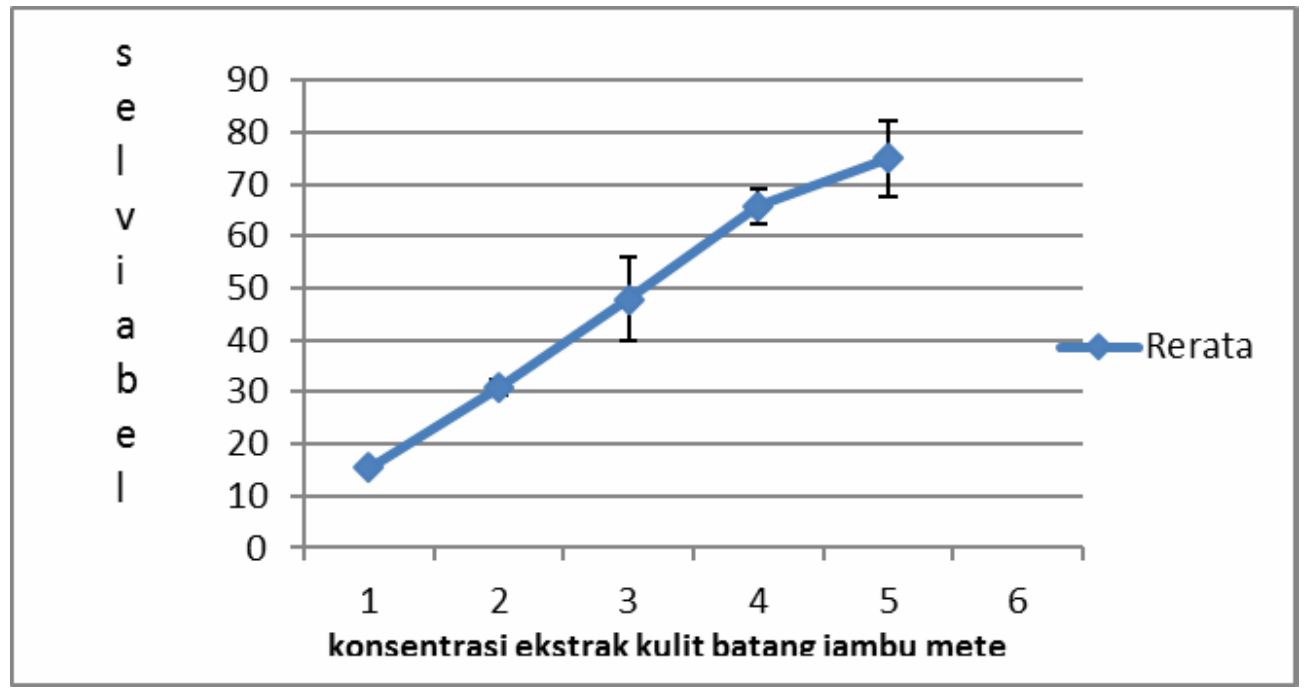

Gambar 2. Grafik rerata viabilitas sel fibroblas

Tabel 1. Rangkuman hasil ANAVA satu jalur pengaruh konsentrasi ekstrak kulit batang jambu mete terhadap viabilitas sel fibroblast

\begin{tabular}{lccccc}
\hline & Jumlah kuadrat & df & Rerata kuadrat & F & Sig. \\
\hline Antar perlakuan & 0,933 & 4 & 0,233 & 144,079 & 0,000 \\
Dalam perlakuan & 0,016 & 10 & 0,002 & & \\
Total & 0,950 & 14 & & \\
\hline
\end{tabular}


Tabel 2. Rangkuman hasil uji post hoc LSD persentase viabilitas sel fibroblast setelah penambahan ekstrak kulit batang jambu mete

\begin{tabular}{cccccc}
\hline \multirow{2}{*}{$\begin{array}{c}\text { Konsentrasi ekstrak kulit batang jambu } \\
\text { mete }\end{array}$} & \multicolumn{5}{c}{ Konsentrasi ekstrak kulit batang jambu mete } \\
\cline { 2 - 6 } & $1,6 \%$ & $0,8 \%$ & $0,4 \%$ & $0,2 \%$ & $0,05 \%$ \\
\hline $1,6 \%$ & - & & & & \\
$0,8 \%$ & $0,30^{*}$ & - & & & \\
$0,4 \%$ & $0,49^{*}$ & $0,19^{*}$ & - & & \\
$0,2 \%$ & $0,63^{*}$ & $0,33^{*}$ & $0,14^{*}$ & - & \\
$0,05 \%$ & $0,69^{*}$ & $0,38^{*}$ & $0,20^{*}$ & 0,055 & \\
\hline
\end{tabular}

Keterangan: *terdapat perbedaan yang bermakna $(p<0,05)$

Hasil uji ANAVA satu jalur pada Tabel 1 menunjukkan bahwa variasi konsentrasi ekstrak kulit batang jambu mete mempunyai pengaruh terhadap toksikitas sel fibroblas $(p<0,05)$. Hal ini sesuai dengan hipotesis yang menyatakan bahwa terdapat pengaruh variasi konsentrasi ekstrak kulit batang jambu mete sebagai bahan kumur terhadap sitotoksikitas sel fibroblas. Kulit batang jambu mete mengandung senyawa antara lain flavonoid, tanin, saponin dan penyusun getah kulit batang jambu mete terdiri dari asam anakardat dan kardol. ${ }^{10}$ Tanin dan flavanoid dalam ekstrak kulit batang jambu mete merupakan golongan fenol. ${ }^{21}$ Senyawa fenol dan turunannya bekerja dengan cara mendenaturasi protein sel di membran sel. Denaturasi protein di membran sel menyebabkan perubahan permeabilitas sel. Hal ini mengakibatkan membran sel tidak dapat mempertahankan komponenkomponen di dalam sel dan mengacaukan aliran bahan yang keluar masuk sel sehingga mengakibatkan sel mati. Menurut Juliantina, ${ }^{22}$ toksikitas tanin dapat merusak membran sel dengan cara mengkerutkan dinding sel atau membran sel sehingga mengganggu permeabilitas dinding sel. Terganggunya permeabilitas sel, sel tidak dapat melakukan aktivitas hidup sehingga sel mati.

Sitotoksisitas suatu bahan mengindikasikan kemungkinan adanya efek toksik yang akan ditimbulkan apabila material tersebut diaplikasikan secara klinis. ${ }^{23}$ Menurut Meric dkk. ${ }^{24}$ sitotoksikitas suatu material dapat diklasifikasikan berdasarkan persentase jumlah sel yang viabel yaitu: a. Tidak sitotoksik: $>90 \%$ sel viabel. b. Sitotoksik ringan: 60 - 90\% sel viabel. c. Sitotoksik sedang: $30-59 \%$ sel viabel dan d. Sitotoksik berat: $<30 \%$ sel viabel
Hasil penelitian ini memperlihatkan viabilitas sel fibroblas dilihat dari hasil grafik I yang dibandingkan dengan Meric memperlihatkan bahwa konsentrasi $1,6 \%$ dengan nilai viabel $15,35 \%$ termasuk sitotoksik berat, konsentrasi 0,8\%-0,4\% dengan nilai viabel $30,84 \%$ dan $47,78 \%$ termasuk sitotoksik sedang dan konsentrasi $0,2 \%-0,05 \%$ dengan nilai viabel $65,74 \%$ dan $74,95 \%$ termasuk sitotoksik ringan.

Hasil uji LSD menunjukkan terdapat perbedaan yang bermakna $(p<0,05)$ antar semua kelompok perlakuan penambahan konsentrasi ekstrak kulit batang jambu mete terhadap viabilitas sel fibroblas kecuali kelompok konsentrasi $0,2 \%$ dan konsentrasi $0,05 \%$ menunjukkan hasil yang tidak signifikan. Menurut Cotran dkk., ${ }^{20}$ bahwa jejas yang terjadi pada sel sangat dipengaruhi oleh berat ringannya stimulus yang diperoleh sel. Konsentrasi bahan kimia diketahui berperan dalam menentukan beratringannya stimulus yang akan mengakibatkan jejas hingga kematian sel. Pada penelitian ini respon jejas sel fibroblas terhadap zat aktif ekstrak kulit jambu mete dengan konsentrasi $0,2 \%$ dan $0,05 \%$ didapatkan hasil yang tidak signifikan. Kematian sel diantaranya dapat disebabkan oleh paparan bahan yang bersifat toksik. Menurut Cotran ${ }^{20}$ jejas sel dapat menimbulkan adaptasi dan kematian sel. Ketika sel sudah tidak mampu beradaptasi terhadap rangsang, maka sel akan mengalami kerusakan dan kematian. Menurut ISO 10993-5 bahwa suatu zat bisa diterima secara klinis apabila viabilitas sel $>70 \%$. Berdasarkan pada penelitian ini disimpulkan bahwa konsentrasi $0,2 \%$ dan $0,05 \%$ ekstrak kulit batang jambu mete aman diaplikasikan secara klinis. 


\section{KESIMPULAN}

Berdasarkan hasil penelitian dapat disimpulkan bahwa: Ekstrak kulitbatang jambu mete mengandung asam anakardat dan asam galat. Konsentrasi $0,2 \%$ merupakan konsentrasi yang tidak toksik terhadap sel fibroblas secara in vitro.

\section{DAFTAR PUSTAKA}

1. Cawson RA, Odell EW. Cawson's essentials of oral pathology and oral medicine, $7^{\text {th }}$ ed. Curchill-Livingstone: Edinburgh; 2008. 220 224.

2. Powers JM, Sakaguci RL. Craig's restorativedental materials, Mosby: USA; 2006. $514-516,524-527$.

3. Harris NO, Christen AG. Primary preventive dentistry, Second Edition, Upper Saddle River, New Jersey; 1997. 157 - 191.

4. Haq MW, Batool M, Ahsan SM, Qureshi NR. Alcohol use in mouthwash and possible oral health concerns. J Pak Med Assoc. 2009; 59(3):186 - 190.

5. Salma. Tujuh keunggulan obat herbal, Majalah Kesehatan. Sumer informasi kesehatan anda; 2010.

6. Kementrian Riset dan Teknologi. Teknologi Tepat Guna (TTG) budidaya pertanian jambu mete. 2005; diakses dari: www.iptek.net.id/ ind/warintek/budidaya_ pertanian. php.html, (30/09/12).

7. Akinpelu DA. Antimicrobial activity of Anacardium occidentale bark. Fitoterapia. 2001; 72: 826 - 827.

8. Prihatman K. Jambu mete, tentang budidaya pertanian, sistem informasi manajemen pembangunan di pedesaan, BAPPENAS, 2000, diakses dari: www.warintek.ristek.go.id/ pertanian/jambu_mete, (12/2/2014).

9. Harsini, Sutardja I, Martono S, Sunarintyas $\mathrm{S}$, Sudarsono. Potensi ekstrak jambu mete (Anacardium occidentale Linn.) sebagai bahan obat kumur. Disertasi program studi ilmu kedokteran kedokteran gigi. FKG, UGM; 2014.

10. Tampubolon O. Tumbuhan obat bagi pencinta alam. Jakarta: Penerbit bhatara; 1995. 101 102.

11. Hegnauer R. Chemotaxonomie der Pflanzen. Stuttgart: Birkhäuser Verlag; 1986. 259-260.

12. Pelzar JM, Chan ECS. Dasar-dasar mikrobiologi 2. Jakarta: Penerbit UI Press; 1998. 457 - 460.

13. Pak E, Esrason KT, Wu VH. Hepato-toxicity of herbal remedie: An emerging dilemma. Prog Transplant. 2004; $14-91-6$.

14. Tédong L, Dzeufiet DDP, Kamtchouing P. Acute and subchronic toxicity of anacardium occidentale linn (anacardiaceae) leaves hexane extract in mice. African Journal of Traditional, Complementary, and Alternative Medicines, Cameroon. 2007; 4(2): 140 - 147.

15. Sakaguchi RL, Powers JM. Craig's restorative dental materials, $13^{\text {th }}$ ed. Philadelphia: Mosby Elsevier Inc; 2012. 327 - 348.

16. Schmalz G. Use of cell cultures for toxicity testing of dental materials: advantages and limitations. J Dent. 1994; 22: 6 - 11.

17. Amalia. Uji sitotoksik ekstrak etanol $70 \%$ buah merica (Piper nigrum L.) terhadap sel hela. Skripsi. Surakarta: Universitas Muhammadiyah Surakarta; 2008. 16.

18. Donatus IA. Toksikologi Dasar, Laboratorium Farmakologi dan Toksikologi Fakultas Farmasi Gadjah Mada, Yogyakarta; 2001. 7.

19. Toxnet. Phenol, National library of medicine, Rockville Pike, United state. 2013; diakses dari: http://toxnet.nlm.nih.gov/cgi-bin, (01/07/2014).

20. Cotran MD, Kumar V, dan Collins T. Robbins pathologic of disease, $6^{\text {th }}$ ed., W.B. Saunders Company, Philadelpia; 1999. $6-8,4-15$, $102-110$. 
21. Akiyama H, Fuji K, Yamasaki O, Oon T, Iwatsuji K. Antibacterial action of several tannins against Staphylococcus aureus. Journal of Antimicrobial Chemotherapy Lawrence. 2001; 48: 487 - 491.

22. Juliantina FR, Citra DA, Nirwani B. Manfaat Sirih Merah (Piper crocatum) sebagai Agen Antibakterial terhadap Bakteri Gram Positif dan Gram Negatif, JKKI; 2009. 1.
23. Brunner TJ, Wick P, Manser P, Spohn P, Grass RN, Limbach LK, Bruinink A, Stark, WJ. In vitro cytotoxicity of oxide nanoparticles: comparison to asbestos, silica, and the effect of particle solubility, Environ Sci Technol. 2006; 40: 4374 $-4381$.

24. Meriç G, Dahl JE, Ruyter IE. Cytotoxicity of silica-glass fiber reinforced composites. Dent Mater. 2008; 24(9): 1201 - 1206. 